\title{
Effect of Organic Farming Practices on Yield and Quality of Cabbage (Brassica oleracea Var. Capitata L.)
}

\author{
M. Prabhakar, A. K. Nair*, S. S. Hebbar, P. Paneerselvam, K. S. Shivashankara, \\ G. A. Geetha, R. S. Rajeshwari and Praveen Kumar \\ ICAR-Indian Institute of Horticultural Research, Bangalore-560089, Karnataka, India \\ *Corresponding author
}

A B S T R A C T

\begin{tabular}{|l|}
\hline Ke y w or d s \\
Organic farming, \\
Cabbage, Yield, \\
Head dry matter, \\
Antioxidant \\
parameters
\end{tabular}

An experiment was conducted in organic vegetable experimental field of IIHR farm, Hesaraghatta, Bengaluru to study the effect of different levels of organic manure in organically and conventionally grown cabbage (Brassica oleracea var. capitata L.) for fruit yield, quality and soil microbial status. The trial included five organic manure treatments comprising 25, 50, 75, $100 \%$ of recommended dose of nitrogen equivalent of FYM and recommended FYM i.e. 25t/ha and two inorganic nutrient treatments viz; recommended FYM @ 25 tonnes/ha + recommended NPK fertilizers and only recommended NPK. The treatment which received recommended FYM + NPK fertilizers produced highest yield of $60.8 \mathrm{t} / \mathrm{ha}$ followed by the treatment which received $100 \%$ of recommended dose of nitrogen $(\mathrm{RDN})$ through organic manure $(50.9 \mathrm{t} / \mathrm{ha})$. The lower head yield of 44.7 and 45.6 t/ha were observed with application of only FYM (25 t/ha) and only NPK fertilizer treatments. Yield attributing parameters like polar circumference $(41.8 \mathrm{~cm})$, equatorial circumference $(49.8 \mathrm{~cm})$ were higher in treatment which received the recommended FYM+ NPK fertilizers. Higher yields with better quality heads were attained with integrated nutrient management and organic treatments as compared to crop grown with only chemical fertilizers.

\section{Introduction}

Increased consumer awareness of food safety issues and environmental concerns has contributed to the development of organic farming over the last few years (Worthington, 2001). Vegetables that are produced by using organic manures are also gaining importance because of less chemical residues and better taste (Patil et al., 2016). Organic production of cabbage, or any commodity, relies on management techniques that replenish and maintain long-term soil fertility by providing optimal conditions for biological activity. Cabbage (Brassica oleracea var. capitata L.) is grown as an annual vegetable crop for its dense-leaved heads.

India is the second largest producer of cabbage in the world with a production of 9.039 million tonnes from an area of 0.400 million hectares (Anon, 2014). 
It is rich in Vitamin A and C as well as food fiber. It is widely consumed around the world as a cooked vegetable as well as fresh in salads, sandwiches, burgers, noodles, pasta etc. Throughout its production cycle, cabbage mostly requires nutrients such as nitrogen, phosphorus and potassium in varying quantities to support optimal growth (Ceronio et al., 2012). Food security and sustainable crop production by small and subsistence producers relies heavily on organic fertilizers as an alternative to inorganic fertilizers. Organic fertilizers can be used to reduce the amount of toxic compound (such as nitrates) produced by conventional fertilizers in vegetables like cabbage, hence, improving the quality of vegetables produced as well as human health. There is little information available on organic production of cauliflower (Prabhakar et al., 2015; Velmurugan et al., 2008). However, there is paucity of information on the use of organic manures for cabbage production and therefore the objective of this study was to standardize organic cultivation practices in cabbage and assess its performance with respect to productivity and quality.

\section{Materials and Methods}

Field experiment was carried out during Rabi seasons of 2012-13 and 2013-14 at ICARIndian Institute of Horticultural Research, Bengaluru. The soil of the experiment site was well drained sandy loam with $\mathrm{pH}$ of 6.81 and EC $0.22 \mathrm{dS} / \mathrm{m}$. The initial organic carbon content of soil was $0.73 \%$ and available $\mathrm{N}$, $\mathrm{P}_{2} \mathrm{O}_{5}$ and $\mathrm{K}_{2} \mathrm{O}$ were 186, 20.9 and $168 \mathrm{~kg} / \mathrm{ha}$ respectively. The experiment was carried out in a randomized block design with three replications, where organic and inorganic plots having similar soil properties were situated 5 meter apart from each other and were separated by a Glyricidia live hedge to protect any possible contamination. The experiment constituted seven treatments, viz
$\mathrm{T}_{1}: 25 \%, \mathrm{~T}_{2}: 50 \%, \mathrm{~T}_{3}: 75 \%, \mathrm{~T}_{4}: 100 \%$ of recommended dose of nitrogen equivalent of FYM application, $\mathrm{T}_{5}$ : recommended FYM only $(25 \mathrm{t} / \mathrm{ha}), \mathrm{T}_{6}$ : conventional practice (recommended FYM @ 25 tonnes/ha + recommended NPK fertilizers) and $\mathrm{T}_{7}$ : only recommended NPK fertilizers. The treatments under organic cultivation received well decomposed FYM as source of nutrient two weeks before planting. Quantity of FYM required for different treatments was calculated on dry weight basis and total nitrogen content of the manure applied. Farmyard manures applied in organic treatments were enriched with bio-fertilizers and bio-agents like Azospirillum, phosphatesolubilizing bacteria (PSB), Pseudomonas fluorescence and Trichoderma harzianum at the rate of $5 \mathrm{~kg}$ each per hectare before field application. The fertilizer dose adopted for inorganic treatment was 150:100:125 kg N: $\mathrm{P}_{2} \mathrm{O}_{5}: \mathrm{K}_{2} \mathrm{O}$ per hectare (Prabhakar et al., 2010). Twenty-two days old seedlings of cabbage cultivar 'Unnati' were planted on raised beds at a spacing of $50 \times 40 \mathrm{~cm}$ accommodating 50000 plants per hectare. The crop was raised with drip irrigation system and daily amount of irrigation water given was to replenish $80 \%$ Epan losses observed in the meteorological observatory located at the IIHR farm, Bengaluru.

Bacteria, fungi and actinomycetes were enumerated from soil samples by serial dilution plate technique, using Nutrient agar, Rose Bengal agar and Kennight respectively. Phosphate solubilizing bacteria and nitrogen fixing bacteria present in the soil samples were enumerated by following the standard procedure using, Nitrogen free semisolid malate medium for Azospirillum (Dobereiner and Day, 1975), Waksmann No. 77 medium for Azotobacter (Allen, 1953) and Pikovskaya's medium for phosphate solubilizing bacteria (Pikovskaya, 1948). The population was expressed as $\mathrm{cfu}^{-1}$ of oven 
dry soil. The dehydrogenase activity was measured in terms of the amount of 2, 3, 5triphenyltetrazolium chloride (TTC) reduced triphenylformazan (TPF) in soils, in triplicates (Thalmann, 1968). Soil respiration estimation was carried out by following method of Alef (1995). The observation on yield and yield parameters were recorded and analyzed by the statistical method adopted by Gomez and Gomez (1983).

\section{Results and Discussion}

The data on yield, yield attributing parameters, head and leaf dry matter content of cabbage are presented in Table 1. The results indicated that there were no significant differences in polar as well as equatorial head circumferences with respect to organic and inorganic treatments tested. However, the results of the experiment indicated that yield component like average head weight was significantly influenced by treatments. Application of recommended FYM + recommended NPK $\left(\mathrm{T}_{6}\right)$ produced significantly higher head weight (1281 g) than all other treatments. Similar results have been reported by Naik et al., (2014) The same treatment recorded highest values for leaf dry matter (18.10\%), while highest head dry matter content $(9.65 \%)$ was recorded in cabbage crop receiving only NPK fertilizers. The higher head dry matter content in only NPK fertilizer treatment might be due to the lower yields with small sized heads having higher concentrations of minerals and other organic substances. The highest yield $(60.8$ t/ha) was recorded with $100 \%$ recommended inorganic fertilizers (NPK) in combination with recommended FYM @ 25 tonnes/ha than other treatments. This could be attributed to the solubilization effect of plant nutrients by addition of organics, leading to increased uptake of NPK, as reported by Subbiah et al., (1982). Among organic treatments higher yields were observed with treatments which received 75 and $100 \%$ of recommended dose of nitrogen equivalent of FYM application. The higher yields in these treatments may be attributed to the regular nutrient availability throughout crop growth period by virtue of higher quantities of nutrient released. Similar findings were reported by Prabhakar et al., (2012) and Gopakalli and Sharanappa (2014) wherein it was found that an increase in onion bulb yield was observed with increase in supply of organic manure to the crops. The lower head yields per hectare were recorded in $\mathrm{T}_{7}(45.6 \mathrm{t} / \mathrm{ha})$ and $\mathrm{T}_{5}$ (44.7 $\left.\mathrm{t} / \mathrm{ha}\right)$, which received only NPK fertilizers and only farm yard manure. This might be due to insufficient nutrient supplied to the cabbage crop, which is known to be heavy feeder of nutrients. These results are also in cognizance with Upadhyay et al., (2015) in cabbage. There was no significant difference among treatments with respect to harvest index. However, organic treatments recorded slightly higher values as compared to inorganic treatments.

The quality parameters like total phenols, flavanoids, Ferric ion Reducing Antioxidant Parameter (FRAP) and 2, 2-diphenyl-1-picrylhydrazyl-hydrate (DPPH) were almost on par in cabbage grown organically or using chemical fertilizers alone or in combination with FYM (Table 2). Maximum total antioxidant capacity was observed in cabbage crop receiving organic manures equivalent to 100 per cent of recommended dose of nitrogen. Similar trend of improved quality parameter with organic treatments were reported in tomato by Kannan et al., (2006) and French beans by Singh (2002).

Many of the antioxidant parameters observed were found to decrease with decrease in amount of organic manure applied. The change in soil microbial properties (Table 3) indicated that the microbial population i.e. bacteria, fungi, Actinobacteria, Azospirillum, 
Azotobacter and Phosphobcateria were found to be increased by 15.0 - 54.3 per cent in organic (i.e. 25,50,75 and $100 \% \mathrm{~N}$ equivalent of FYM) and conventional treatment which received farm yard manure as compared to treatment received only NPK fertilizers. Krishnakumar et al., (2005) and Chang et al., (2007) also observed increase in soil microbial population with application of organic manure and neem cake. The soil respiration and dehydrogenase activity were observed to be increased by 7.6 - $36.1 \%$ in organic treatments $\left(\mathrm{T}_{1}-\mathrm{T}_{4}\right)$ as compared to only inorganic fertilizers application $\left(\mathrm{T}_{7}\right)$. In general, soil dehydrogenase activity reflects the total range of oxidative activity of soil microflora and is consequently used as an indicator of microbial activity (Masciandaro et al., 1994; Perucci 1992).

In general, FYM alone treatments and FYM plus NPK treatment found to enhance the microbial properties compared to only inorganic fertilizers application. This might be due to increased soil enzyme activities viz., dehydrogenase and phosphatase observed to be higher in organic manure amended treatments as compared to only inorganic fertilizer application (Krishnakumar et al., 2005; Chang et al., 2007).

Table.1 Dry matter, yield and yield components of cabbage in relation to organic treatments (pooled data)

\begin{tabular}{|c|c|c|c|c|c|c|c|}
\hline Treatment & $\begin{array}{c}\text { Polar } \\
\text { circumference } \\
(\mathbf{c m})\end{array}$ & $\begin{array}{c}\text { Equatorial } \\
\text { circumference } \\
\mathbf{( c m )}\end{array}$ & $\begin{array}{c}\text { Average } \\
\text { head } \\
\text { weight } \\
\mathbf{( g )}\end{array}$ & $\begin{array}{c}\text { Head } \\
\text { dry } \\
\text { matter } \\
(\mathbf{\%})\end{array}$ & $\begin{array}{c}\text { Leaf dry } \\
\text { matter } \\
(\mathbf{\%})\end{array}$ & $\begin{array}{c}\text { Yield } \\
\text { (t/ha) }\end{array}$ & $\begin{array}{c}\text { Harvest } \\
\text { Index }\end{array}$ \\
\hline $\mathbf{T}_{\mathbf{1}}$ & 36.70 & 47.13 & 1040 & 7.96 & 16.35 & 47.0 & 0.84 \\
\hline $\mathbf{T}_{\mathbf{2}}$ & 39.20 & 46.43 & 1048 & 8.23 & 17.75 & 47.5 & 0.81 \\
\hline $\mathbf{T}_{\mathbf{3}}$ & 40.13 & 46.30 & 1103 & 8.23 & 16.16 & 50.3 & 0.81 \\
\hline $\mathbf{T}_{\mathbf{4}}$ & 40.70 & 44.93 & 1118 & 8.52 & 15.33 & 50.9 & 0.81 \\
\hline $\mathbf{T}_{\mathbf{5}}$ & 39.77 & 46.87 & 1012 & 8.20 & 16.44 & 44.7 & 0.77 \\
\hline $\mathbf{T}_{\mathbf{6}}$ & 41.80 & 49.80 & 1281 & 8.86 & 18.10 & 60.8 & 0.79 \\
\hline $\mathbf{T}_{\mathbf{7}}$ & 37.03 & 46.67 & 1008 & 9.65 & 17.08 & 45.6 & 0.79 \\
\hline $\mathbf{C D}$ & $\mathrm{CS}$ & $\mathrm{NS}$ & 63.8 & 0.70 & 2.10 & 9.23 & $\mathrm{NS}$ \\
\hline $\mathbf{p = 0 . 0 5}$ & & & & & & & \\
\hline
\end{tabular}

Table.2 Antioxidant parameters of cabbage $(\mathrm{mg} / 100 \mathrm{~g}$ dry weight) in selected organic and inorganic treatments (Pooled data)

\begin{tabular}{|c|c|c|c|c|c|}
\hline Treatment & Phenols & Flavonoids & FRAP & DPPH & Vit C \\
\hline $\mathbf{T}_{\mathbf{1}}$ & 288.47 & 20.56 & 206.49 & 391.64 & 460.71 \\
\hline $\mathbf{T}_{\mathbf{3}}$ & 328.70 & 20.44 & 219.13 & 442.83 & 441.06 \\
\hline $\mathbf{T}_{\mathbf{4}}$ & 345.01 & 27.20 & 217.42 & 420.19 & 476.00 \\
\hline $\mathbf{T}_{\mathbf{6}}$ & 339.68 & 23.41 & 204.39 & 443.19 & 377.38 \\
\hline $\mathbf{T}_{\mathbf{7}}$ & 326.74 & 20.18 & 201.54 & 394.77 & 489.02 \\
\hline
\end{tabular}


Table.3 Soil microbial population (cfu/g), soil respiration and dehydrogenase activity after cabbage crop

\begin{tabular}{|c|c|c|c|c|c|c|c|c|}
\hline Treatment & $\begin{array}{c}\text { Bacteria } \\
\left(\mathbf{1 0}^{8} \mathrm{~g}^{-1}\right. \\
\text { soil })\end{array}$ & $\begin{array}{c}\text { Fungi } \\
\left(10^{4} \mathrm{~g}^{-}\right. \\
\left.{ }^{-} \mathrm{soil}\right)\end{array}$ & $\begin{array}{c}\text { Actiono- } \\
\text { bacteria } \\
\left(10^{5} \mathrm{~g}^{-1}\right. \\
\text { soil })\end{array}$ & $\begin{array}{c}\text { Azospirillu } \\
m \text { spp. } \\
\left(10^{5} \mathrm{~g}^{-1}\right. \\
\text { soil })\end{array}$ & $\begin{array}{c}\text { Azotobacte } \\
r \text { spp. } \\
\left(10^{5} \mathrm{~g}^{-1}\right. \\
\text { soil })\end{array}$ & $\begin{array}{c}\text { Phosphate } \\
\text { solubilizing } \\
\text { microbes } \\
\left(\mathbf{1 0}^{5} \mathrm{~g}^{-1} \text { soil }\right)\end{array}$ & $\begin{array}{c}\text { Soil } \\
\text { respiration } \\
(C \\
\mathrm{mg} / \mathrm{kg} / \mathrm{hr})\end{array}$ & $\begin{array}{c}\text { Dehydrogenase } \\
\text { activity } \\
(\mu \mathrm{g} \text { of } \mathrm{TPF} \\
\text { released/g of } \\
\text { soil per hour) }\end{array}$ \\
\hline $\mathbf{T}_{1}$ & 24.6 & 8.7 & 8.0 & 6.4 & 5.7 & 13.2 & 9.1 & 117.1 \\
\hline $\mathbf{T}_{2}$ & 29.6 & 9.2 & 6.2 & 7.3 & 6.8 & 13.6 & 10.3 & 123.1 \\
\hline $\mathbf{T}_{3}$ & 20.8 & 5.9 & 5.7 & 7.0 & 5.3 & 13.0 & 7.1 & 100.7 \\
\hline $\mathbf{T}_{4}$ & 23.6 & 7.8 & 5.4 & 6.9 & 7.2 & 14.2 & 6.5 & 86.3 \\
\hline $\mathbf{T}_{5}$ & 26.2 & 6.7 & 6.8 & 8.3 & 6.1 & 11.4 & 6.7 & 89.4 \\
\hline $\mathbf{T}_{6}$ & 22.6 & 8.1 & 7.8 & 8.1 & 7.0 & 14.0 & 6.2 & 76.9 \\
\hline $\mathbf{T}_{7}$ & 19.2 & 4.2 & 3.8 & 5.1 & 3.8 & 7.4 & 6.0 & 78.6 \\
\hline
\end{tabular}

Note : Cfu - Colony forming unit, C-Carbon, TPF- Triphenylformazan

From this result it is clearly evident that organic cabbage production is feasible by following appropriate scientific organic farming practices with emphasis on organic nutrient supply through locally available manures enriched with suitable biofertilizers and bioagents and following organic plant protection procedures. The yield performance under organic treatments is comparable to that of conventionally grown cabbage.

\section{References}

Alef, K. 1995. Soil respiration. In: Methods in applied soil microbiology and biochemistry, K. Alef and P., Nannipieri (Eds). Academic Press, London. pp. 214219.

Allen, O. N. 1953. Experiments in soil bacteriology. Burgess Publishing Company, Minneapolis, Minn., U.S.A. pp. 69-70.

Anonymous, 2014. All India Area production and productivity of cabbage. Indian Horticulture

Database.http://www/nhb.gov.in/

Ceronio, G. M., Engelbrecht, G. M. and
Mbatha, A. N. 2012. Organic fertilizer use and the potential influence on cabbage (Brassica oleracea var. capitata L.) plant and soil nutrient composition, Acta Horticulturae. 938: 265-271.

Chang, E. H., Chung, R. S. and Tsai, Y. H. 2007. Effect of different application rates of organic fertilizer on soil enzyme activity and microbial population. Soil Sci. and Plant Nutri. 53: 132-140.

Dobereiner, J. and Day, M. 1975. Associative symbioses in tropical grasses; characterization of microorganisms and nitrogen-fixing sites. In: Proceedings of the $I^{\text {st }}$ International Symposium on $\mathrm{N}_{2}$ Fixation, Vol.2, W.E.Newton (Ed).

Gomez, K. A. and Gomez, A. A. 1983. Statistical Procedure for Agricultural Research. Second edition. A WileyInternational Science Publication, New York, United States of America.

Gopakalli, P. and Sharanappa. 2014. Effect of organic farming practices on growth, yield, quality and economics of onion (Allium cepa) in dry zone of Karnataka, Indian J. Agron. 59: 336:340.

Kannan, P., Saravanan, A. and Balaji, T. 2006. 
Organic farming on tomato yield and quality. Crop Res. 32: 196-200.

Krishnakumar, S., Saravanan, A., Natarajan, S. K., Veerabadran, V. and Mani, S. 2005. Microbial population and enzymatic activity as influenced by organic farming. Res. J. Agric. Biol. Sci. 1: 85-88.

Masciandaro, G., Ceccanti, B. and Garcia, C. 1994. Anaerobic digestion of straw and piggery waste waters. II. Optimization of the process. Agrochimica. 38: 195-203.

Naik,V.R., Patel, P.B. and Patel, B.K. 2014. Study on effect of different organics in yield and quality of organically grown onion. The Bioscan. 9: 1499-1503

Patil, Anand G., Mangesh and Rajkumar, M.2016. Integrated nutrient management in carrot (Daucus carota L.) under north eastern transitional track of Karnataka. The Bioscan. 11: 271-273

Perucci, P. 1992. Enzyme activity and microbial biomass in a field amended with municipal refuse. Biol. Fertil. Soils. 14: 54-60.

Pikovskaya, R. I. 1948. Mobilization of phosphorus in soil connection with vital capacity of source microbial species. Microbiologiya. 17: 362-370.

Prabhakar, M., Hebbar, S. S. and Nair, A. K. 2010. Production technology of vegetables -A Hand book. 2010. ICARIndian Institute of Horticultural Research, Bengaluru, Karnataka

Prabhakar, M., Hebbar, S. S. and Nair, A. K. 2012. Effect of organic farming practices on growth, yield and quality of rose onion (Allium cepa). Indian J. Agril. Sci. 82: 500-503.

Prabhakar, M., Hebbar, S. S., Nair, A. K., Shivashankara, K.S., Chinnu, J.K. and
Geetha, G.A. 2015. Effect of different organic nutrient levels on growth, yield and quality in cauliflower. Indian $J$. Hort.72: 293-296

Singh, S. R. 2002. Effect of organic farming on productivity and quality of French bean (Phaselous vulgaris L.) var. Contender. Legume Res. 25: 124-126.

Subbiah. K., Helkiah. J., Ravi Kumar. V. and Rajagopal, C.K. 1982. Effect of combined application of organic and inorganic fertilizers on yield and nutrient uptake of MDU chilli. South Ind. Hort. 30: 45-47

Thalmann, A.1968. Zur methodik der Bestimmung der Dehydrogenase aktivit At im Boden mittels triphenytetrazolium chloride (TTC). Landwirtsch. Forsch. 21: 249-258.

Upadhyay, A. K.,Jagdish, S., Anant, B., Singh, V. K. and Singh, S. K. 2015. Impact of integrated nutrient management on yield, quality traits and economics of cabbage (Brassica oleracea L. var. capitata). Progressive Hort. 47: 122-126.

Velmurugan, M., Balakrishnamoorthy, G.,Rajamani, K., Shanmugasunderam, P. and Gnanam, R. 2008. Effect of organic manures, biofertilizers and bio-stimulants on growth and yield of cauliflower (Brassica oleracea var. botrytis) cv. Indam 2435. Crop Res. 35: 42-45.

Weinberger, K. and Srinivasan, R. 2009. Farmers management of cabbage and cauliflower pests in India and their approaches to crop protection. J AsiaPacific Ento. 12: 253-259.

Worthington, V. 2001. Nutritional quality of organic versus conventional fruits, vegetables and grains. J. Alternative Complent. Med. 7: 161-173.

\section{How to cite this article:}

Prabhakar. M., A. K. Nair, S. S. Hebbar, P. Paneerselvam, K. S. Shivashankara, G. A. Geetha, R. S. Rajeshwari and Praveen Kumar. 2020. Effect of Organic Farming Practices on Yield and Quality of Cabbage (Brassica oleracea Var. Capitata L.). Int.J.Curr.Microbiol.App.Sci. 9(07): 615-620. doi: https://doi.org/10.20546/ijcmas.2020.907.069 